\title{
CREDIT RATIONING FOR PORTUGUESE SMES
}

Financial Stability Papers

BANCO DE PORTUGAL Luísa Farinha|Sónia Félix
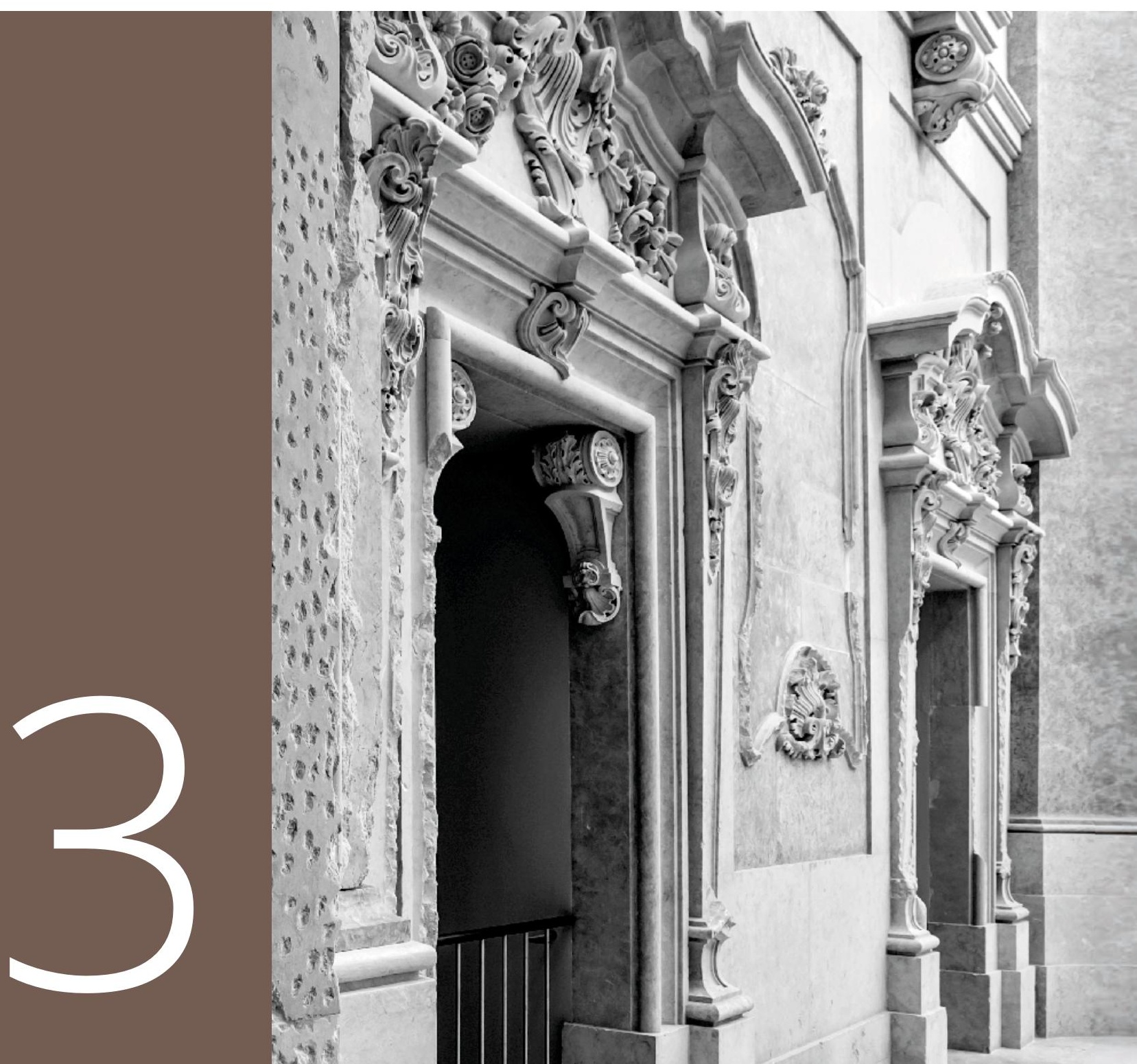



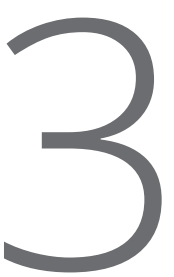

CREDIT RATIONING FOR PORTUGUESE SMES

Financial Stability Papers

Luísa Farinha | Sónia Félix 
FINANCIAL STABILITY PAPERS | November 2014 • Banco de Portugal Av. Almirante Reis, 71 | 1150-012 Lisboa • www.bportugal.pt - Edition Financial Stability Department • Design, printing and finishing • Administrative Services Department | Editing and Publishing Unit • ISBN 978-989-678-312-9 (online) • ISSN 2183-4059 (online) 


\title{
Credit rationing for Portuguese SMEs*
}

\author{
Luísa Farinha ${ }^{\dagger} \quad$ Sónia Félix ${ }^{\ddagger}$
}

\begin{abstract}
This study examines the importance of credit demand and credit supply-related factors in explaining the evolution of credit granted to Portuguese small and medium-sized enterprises (SMEs). The results suggest that the interest rate is a strong driver of SMEs' demand for bank loans, as well as their internal financing capacity. On the other hand, credit supply mostly depends on the firms' ability to generate cash-flows and reimburse their debt, and on the amount of assets available to be used as collateral. The model was estimated for the period between 2010 and 2012, and the estimated coefficients were used to compute the probability of credit rationing. The results suggest that a considerable fraction of Portuguese SMEs were affected by credit rationing in this period.
\end{abstract}

JEL Classification: E51, G21

Keywords: Credit rationing, Bank loans, Financial crisis, SMEs, Disequilibrium model

*We are grateful to Elisabeth Kremp and Patrick Sevestre for their help in programming the disequilibrium model and to Diana Bonfim, Inês Drumond, Maximiano Pinheiro and Pedro Portugal for their comments and suggestions. The views expressed are those of the authors and do not involve the responsibility of the Banco de Portugal or the Eurosystem.

${ }^{\dagger}$ Banco de Portugal; E-mail: lfarinha@bportugal.pt.

${ }^{\ddagger}$ Banco de Portugal and Nova School of Business and Economics; E-mail: scfelix@bportugal.pt. 


\section{Introduction}

In the years that preceded the recent crisis, the Portuguese non-financial corporations accumulated high levels of debt, with the ratio between the non-financial corporate sector debt and GDP registering values higher than 130 percent $^{1}$ in $^{2008}$. This evolution of credit was induced by favorable financing conditions and optimistic expectations of productivity growth that did not materialize, highlighting the need for an adjustment process. The global financial crisis and the subsequent sovereign debt crisis led to an adjustment process characterized by a significant contraction of the economic activity and worse prospects of economic agents. Furthermore, this adjustment involved a bank lending channel with the Portuguese banks being severely affected by international financing restrictions and stronger capital requirements. In this context, the adjustment process comprised a simultaneous contraction in the demand and supply of credit. It is important to note that, according to the Bank Lending Survey (BLS), the observed credit evolution during the economic and financial crisis was a result of increased restrictiveness in credit standards and conditions applied on loans as well as of decreased loan demand by firms. Nevertheless, it is a difficult task to rigorously evaluate the relative contribution of each dimension ${ }^{2}$.

The availability of microeconomic datasets with a maximum level of granularity has been crucial for the development of new approaches to the identification of credit rationing of non-financial corporations. Antunes and Martinho (2012) used data for the period between the first quarter of 1995 and the first quarter of 2012 and estimated a model to explain the evolution of credit granted by Portuguese banks to non-financial corporations, to examine the eventual presence of credit restrictions. Even though this analysis does not allow to unequivocally identify the relative contribution of credit demand and credit supply to explain the evolution of credit, the results suggest that the access to credit by Portuguese firms became more difficult after 2009 and that credit restrictions were particularly relevant for firms seeking credit for the first time.

\footnotetext{
${ }^{1}$ This value refers to the ratio between the non-financial corporate sector debt and GDP in consolidated terms and according to ESA 1995.

${ }^{2} \mathrm{An}$ analysis of this topic using the BLS data can be found in the Box 1.2.1 "Decomposing credit growth on the basis of the Bank Lending Survey", published in the Financial Stability Report of Banco de Portugal, November 2013. The authors construct indices based on the qualitative answers of bank officials on developments in the credit market and include these indices as explanatory variables in a model to explain credit growth.
} 
Farinha and Félix (2014) considered an econometric methodology similar to that in Rottmann and Wollmershäuser (2013) and estimated a two-step model to evaluate the importance of credit demand and credit supply factors in explaining the evolution of credit in the period between the first quarter of 1997 and the second quarter of 2013. The results suggest that after controlling for firm idiosyncratic characteristics, the evolution of credit is largely explained by banks liquidity and solvency conditions. The fact that banks react in a significant way to changes in their liquidity structure and to stricter minimum capital requirements, with banks with less access to funding and smaller capital buffers granting less credit, evidences the presence of a bank lending channel through which banks can affect firms financing conditions (assuming that at least a fraction of firms does not have easy access to alternative sources of financing) ${ }^{3}$. Nevertheless, this analysis is only indicative of the presence of credit restrictions in the Portuguese economy.

The disequilibrium models originally developed to evaluate the presence of credit rationing at the macroeconomic level (see, for example, Laffont and Garcia (1977)), have been used more recently in the empirical literature to identify credit restrictions based on microeconomic data. These models assume that the credit market may be in disequilibrium and, therefore, the observed interest rate does not ensure that credit demand is equal to credit supply. Ogawa and Suzuki (2000), Atanasova and Wilson (2004), Shikimi (2005) and Carbo-Valverde, Rodríguez-Fernandez, and Udell (2009) estimated disequilibrium models to identify the presence of credit rationing in the economy. More recently, Kremp and Sevestre (2013) considered this methodology to analyse the determinants of credit demand and credit supply for French small and medium-sized enterprises (SMEs) and found that, even though banks adopted tighter standards in credit approval, French firms were not significantly affected by credit rationing, even after 2008.

In this study we aim to assess the importance of credit demand and credit supplyrelated factors in explaining the evolution of credit granted to Portuguese SMEs and evaluate whether this evolution stems from a more restrictive credit policy in the period between 2010 and 2012. We restrict our sample to SMEs since they are expected to rely more on bank loans and to have less access to external sources of financing,

\footnotetext{
${ }^{3}$ This result contributes to the discussion on the bank lending channel and bank capital channel (see Adelino and Ferreira (2014) for a concise resume of this literature).
} 
namely financing by non-resident banks. Therefore, it is expected that SMEs are potentially the most affected by credit restrictions. For that purpose, we consider a methodology that allows to simultaneously estimate credit supply and demand functions, assuming that the credit market may be in disequilibrium, as modeled in Kremp and Sevestre (2013).

The results suggest that credit supply depends positively on the amount of assets available to be provided as collateral and negatively on firms' indebtedness. In turn, credit demand depends negatively on the interest rate and the amount of firms' internal resources, and positively on their working capital needs. We estimate that approximately 15 percent of Portuguese SMEs with bank loans were partially rationed and 32 percent of firms with no bank loans were fully rationed.

The paper is organized as follows: in the next section we present the model and the variables considered in the analysis and in section 3 we discuss some econometric questions. In section 4 we present the methodology to evaluate the intensive and extensive margins of credit rationing. The data and main descriptive statistics are presented in section 5 . In section 6 we discuss the main results and section 7 concludes.

\section{The demand and supply of credit: model and variables}

\subsection{The disequilibrium model}

Essentially, a disequilibrium model comprehends three equations: one equation for credit demand, one equation for credit supply, and one additional equation that links credit demand to credit supply. In the case of the credit market (see, for example, Laffont and Garcia (1977)), the disequilibrium model is made of the following three equations:

(a) An equation for the demand of new loans, $N L_{d}^{\star}$ :

$$
N L_{d}^{\star}=f_{d}\left(X_{d} b_{d} ; u_{d}\right)
$$

(b) An equation for the supply of new loans, $N L_{s}^{\star}$ : 


$$
N L_{s}^{\star}=f_{s}\left(X_{s} b_{s} ; u_{s}\right)
$$

where $X_{d}$ and $X_{s}$ represent the vectors of explanatory variables that affect credit demand and credit supply, respectively, and $b_{d}$ and $b_{s}$ are the vectors of coefficients associated with those variables. The terms $u_{d}$ and $u_{s}$ with zero mean and variance $\sigma_{d}^{2}$ and $\sigma_{s}^{2}$, respectively, represent the unobservable factors that affect credit demand and credit supply, respectively, and it is assumed that they may be correlated with each other $(\rho)$.

(c) An equation that links the observed quantity of credit with the unobservable credit demand and supply. This equation assumes that the observed quantity of credit is the minimum between the demand and the supply:

$$
N L=\min \left(N L_{d}^{\star}, N L_{s}^{\star}\right)
$$

This system of equations is estimated using the maximum likelihood estimator (see Maddala and Nelson (1974)).

When the demand and supply of credit are strictly positive and the interest rate is observed, the contribution to the maximum likelihood function is

$$
I_{i t}=f_{d}\left(N L_{i t}\right)\left(1-F_{s}\left(N L_{i t}\right)\right)+f_{s}\left(N L_{i t}\right)\left(1-F_{d}\left(N L_{i t}\right)\right)
$$

where

$f_{d}\left(N L_{i t}\right)=\frac{1}{\sigma_{d} \sqrt{2 \pi}} \exp \left[-\frac{1}{2 \sigma_{d}^{2}}\left(N L_{i t}-X_{d, i t} b_{d}\right)^{2}\right]$, is the density function of new loans if the demand is observed;

$F_{d}=\Phi\left(\frac{N L_{i t}-X_{d, i t} b_{d}-\rho\left(\sigma_{d} / \sigma_{s}\right)\left(N L_{i t}-X_{s, i t} b_{s}\right)}{\sigma_{d}^{2} \sqrt{1-\rho^{2}}}\right)$, is the corresponding cumulative distribution function which considers the possibility that credit demand and credit supply may be correlated;

$f_{s}\left(N L_{i t}\right)=\frac{1}{\sigma_{s} \sqrt{2 \pi}} \exp \left[-\frac{1}{2 \sigma_{s}^{2}}\left(N L_{i t}-X_{s, i t} b_{s}\right)^{2}\right]$, is the density function of new loans if the supply is observed; 
$F_{s}=\Phi\left(\frac{N L_{i t}-X_{s, i t} b_{s}-\rho\left(\sigma_{s} / \sigma_{d}\right)\left(N L_{i t}-X_{d, i t} b_{d}\right)}{\sigma_{s}^{2} \sqrt{1-\rho^{2}}}\right)$, is the corresponding cumulative distribution function.

\section{$2.2 \quad$ Variables}

In this section we present the variables included in the model. We consider that the demand for new loans depends on the following factors:

Firm size - smaller firms are expected to have more difficulties in accessing credit from sources other than bank loans and, simultaneously, are the most affected by credit restrictions due to their financial structure and their higher exposure to information asymmetries. This paper voluntarily restricts the analysis to SMEs. We consider three size categories: very small firms, small firms, and medium-sized firms ${ }^{4}$.

Interest rate - it is included in the demand function as a measure of the firm's financing costs and is calculated by dividing the interest expenses by the firm's total debt ${ }^{5}$.

Short-term financing needs - the ratio between the firm's working capital needs and total assets is included in the analysis as a measure of the firm's short-term financing needs.

Long-term financing needs - the investment, calculated as the ratio between the first differences of tangible assets and total assets, is considered as a measure of long-term financing needs.

\footnotetext{
${ }^{4}$ According to the European classification of SMEs, very small enterprises are defined as enterprises which employ fewer than 10 persons, their sales do not exceed 200 thousand euro or their turnover does not exceed 2 million euro. Small enterprises employ between 10 and 50 persons, their sales range between 200 thousand and 10 million euro or their turnover between 2 million and 10 million euro. The medium-sized enterprises employ between 50 and 250 persons, their sales range between 10 million and 43 million euro or their turnover between 10 million and 50 million euro.

${ }^{5}$ The interest rate is only considered in the demand function following Ogawa and Suzuki (2000), Atanasova and Wilson (2004), Shikimi (2005) and Kremp and Sevestre (2013). In fact, it is considered that in a context of credit restrictions, banks first decide on the amount they are willing to lend and then bargain the interest rate with firms. The decision of granting credit to a firm is determined by variables other than the interest rate, namely the firm idiosyncratic characteristics.
} 
Amount of internal resources - the pecking order hypothesis says that firms with higher capacity to finance their activity through internal resources are less likely to seek bank loans since the latter have a higher cost, in particular for smaller firms more exposed to information asymmetries; nevertheless, firms may decide to increase their debt if the advantages associated with debt exceed the costs (namely, firms may benefit from fiscal advantages); the considered measure for the amount of internal resources is the ratio between the firm's operational results (EBITDA) ${ }^{6}$ and total assets.

Other sources of external financing - the non-financial debt that, in the case of SMEs, is largely composed by loans granted by shareholders and accounts payable, is an alternative source of financing less costly than bank loans; therefore, we include in the demand function the difference between firm's total debt and debt to credit institutions, and the accounts payable, measured in terms of total assets.

Time and sectoral dummy variables - time dummies are included in the demand equation to account for macroeconomic shocks that affect firms' credit demand and sectoral dummies to capture sector systematic differences in credit demand.

On the other hand, the following determinants are considered in the equation of credit supply:

Firm size - this variable reflects the credit risk associated with a given firm since firms' survival probability is lower for small firms and the risk to go bankrupt is higher for these firms when compared to larger firms.

Age of the firm - the default risk is higher for younger firms (see, for example, Fougère, Golfier, Horny, and Kremp (2012)). The analysis includes an indicator variable equal to one for firms less than or five years old, and zero for older firms.

Ratio between financial debt and operational results - measures the capacity of the

\footnotetext{
${ }^{6}$ The operational result is considered as a proxy variable for the amount of internal resources. In fact, this variable can be interpreted as a measure of the potential amount of internal resources that the firm may decide to retain or distribute as dividends.
} 
firm to generate cash-flows to pay its debt and is also a measure of credit risk: it is evaluated by the ratio between the firm's total debt and the operational results (EBITDA), lagged by one period.

Collateral - the ability to provide collateral when negotiating a bank loan limits the losses to be faced in the case of firm's bankruptcy; the indicator used is the ratio between tangible assets and total assets.

We also consider time and sectoral dummy variables to account for common shocks in the supply of credit and sectoral idiosyncratic characteristics constant over time.

\section{Some econometric questions}

\subsection{New loans}

Using firm's balance-sheet information to compute the amount of bank loans does not allow to immediately identify new loans. In this paper, we follow the same econometric strategy considered in Kremp and Sevestre (2013) and include in the analysis a set of lagged terms of the dependent variable, calculated within the firms' sector and dimension category, imposing that the estimated coefficient is the same in both the credit demand and credit supply equations. This is equivalent to assume the following relation:

$$
N L_{i t}=L_{i t}-\left(1-\delta_{g}\right) L_{i t-1}
$$

where $\delta_{g}$ is a reimbursement rate assumed to be constant over time and common to firms within a given sector and dimension category.

\subsection{Endogeneity and unobservable heterogeneity}

Some of the variables included in the econometric model can raise endogeneity problems. More precisely, we assume that the amount of collateral in the supply equation, and that of investment, working capital needs and the interest rate in the demand 
equation, may be endogenous variables ${ }^{7}$. In fact, the firm's amount of investment and collateral may depend on the amount of the loan it was granted; likewise the working capital needs and the accounts payable depend on the firm's activity levels that, in its turn, may be affected by the firm's access to bank loans. On the other hand, the interest rate may also be endogenous because firms negotiate with banks the loan amount as well as the price. To limit endogeneity problems in the model estimation we follow the strategy used in Kremp and Sevestre (2013) and developed by Rivers and Vuong (1988), that consists in the introduction of the residuals of the estimation of each endogenous variable on a set of instruments (first differences of the explanatory variables lagged one and two periods) in the equations of credit demand and supply.

The firms' unobservable characteristics that may influence the demand and supply of credit potentially correlated with the explanatory variables may also raise an estimation issue. To account for the bias that omitted variables may induce in the estimation, we include the sample averages of the explanatory variables as well as the first observation of the dependent variable in the equations of demand and supply of new loans (combination of the solutions proposed by Mundlak and Wooldridge).

\section{Credit rationing}

The estimation of the equations for credit demand and supply allows to calculate in what extent the Portuguese SMEs faced credit restrictions in the sampling period. Based on the estimates, it is possible to identify which firms obtained a loan but in a lower amount than they applied for - intensive margin - and in what extent firms that did not get any loan were fully rationed - extensive margin.

The probability of credit rationing considered in the analysis is the probability that the latent credit demand is higher that the supply of credit, conditional on the observed amount of loans, as proposed by Gersovitz (1980):

\footnotetext{
${ }^{7}$ The firm's amount of collateral, investment, working capital needs and accounts payable are measured in terms of total assets.
} 


$$
\operatorname{Pr}\left(\text { Rationing } \mid N L_{i t}\right)=\frac{f_{s}\left(N L_{i t}\right)\left(1-F_{d}\left(N L_{i t}\right)\right)}{f_{d}\left(N L_{i t}\right)\left(1-F_{s}\left(N L_{i t}\right)\right)+f_{s}\left(N L_{i t}\right)\left(1-F_{d}\left(N L_{i t}\right)\right)}
$$

We consider that a firm was affected by credit restrictions if this probability is greater than 0.5 .

To assess the extensive margin of credit rationing it is necessary to estimate an interest rate for those firms with no bank loans. In the case of firms with no bank loan in a given year but that had access to bank loans in other years, the interest rate is calculated as follows:

$$
\widehat{i}_{i t}=i_{i t-1} \times\left(1+\Delta r_{j t}\right)
$$

where $\widehat{i}_{i t}$ is the estimated interest rate for firm $i$ in year $t, i_{i t-1}$ is the last observation of the firm's interest rate, and $\Delta r_{j t}$ is the average growth of the interest rate between $t-1$ and $t$, within activity sector and size dimension.

In the case of firms with no bank loans in the sampling period, the estimated interest rate is the average interest rate calculated by size category and sector of activity.

\section{Data}

The variables included in the analysis were computed using the Portuguese dataset Simplified Corporate Information (Portuguese acronym for Informação Empresarial Simplificada - IES), which comprehends detailed balance-sheet information on the universe of Portuguese non-financial corporations. This dataset is also the data source for bank loans, and therefore it is not possible to decompose the total amount of bank loans by bank. Consequently, the specification we developed for the supply of credit does not take into consideration bank specific factors such as the banks solvency and liquidity positions. The IES information is available for the period between 2005 and 2012. We consider a sample of small and medium Portuguese firms because those are the most exposed to credit restrictions. The activity sectors included in the analysis comprise manufacturing industry, construction and real estate, trade, and the different 
segments of services.

The relevant period for the estimation starts in 2010 because we impose that firms stay at least for four consecutive years in the sample. This restriction is justified by the inclusion of the first differences and the first and second lags of the first differences in the estimation as instruments for the endogenous variables. We considered the observations above the 99th percentile or below the 1st percentile as outliers.

The sample includes 50020 observations with positive bank loans and observed interest rate. The main descriptive statistics associated to the variables considered in the analysis are reported in Table 1 . The sample is mostly constituted by small and medium-sized enterprises that belong to the trade and manufacturing industry sectors. Over the sample period, the disinvestment of Portuguese SMEs is particularly evident. It is also possible to find that Portuguese SMEs mostly rely on bank loans and accounts payable as financing sources of their activity. The firms' non-financial debt corresponds only to a small part of their total assets.

\section{$6 \quad$ Estimation results}

\subsection{Disequilibrium model}

The main estimation results of the equations of demand and supply of new loans are presented in Table $2^{8}$. The coefficients reported in the first column were obtained assuming that credit demand and supply are independent and those reported in the third column were obtained assuming that credit demand and supply may be correlated. The coefficients are mostly statistically significant and have the expected sign, with the exception of firm size in the credit supply equation.

The results of the estimation of the credit supply equation in both models suggest that the credit ceiling is higher for firms of smaller dimension, controlling for the other firm characteristics. The estimated coefficient for the ratio between debt and operational results indicate that it is more difficult for indebted firms to have access to bank loans. In fact, firms with a stronger relative weight of debt have less capacity to generate cash-flows to reimburse what they have borrowed and have, therefore, a higher risk of default. The importance of collateral in the banks' decision to grant

\footnotetext{
${ }^{8}$ The remaining estimated coefficients are reported in Tables A1 and A2 in the appendix.
} 
Table 1 - Main descriptive statistics

\begin{tabular}{|c|c|c|c|c|c|}
\hline & Mean & St. Dev. & Q1 & Q2 & Q3 \\
\hline Total assets & 1938798 & 11900000 & 231248.1 & 558436.7 & 1456533 \\
\hline Loans/Assets & 0.248 & 0.170 & 0.110 & 0.222 & 0.358 \\
\hline EBITDA/Assets & 0.059 & 0.133 & 0.036 & 0.068 & 0.113 \\
\hline Interest rate & 0.051 & 0.045 & 0.023 & 0.041 & 0.065 \\
\hline Investment/Assets & -0.014 & 0.078 & -0.038 & -0.014 & 0.001 \\
\hline Collateral/Assets & 0.245 & 0.214 & 0.069 & 0.186 & 0.370 \\
\hline Non-financial debt/Assets & 0.054 & 0.112 & 0.000 & 0.001 & 0.056 \\
\hline$(\text { Debt/EBITDA })_{t-1}$ & 2.857 & 7.994 & 0.846 & 2.487 & 5.098 \\
\hline Accounts payable/Assets & 0.217 & 0.175 & 0.083 & 0.180 & 0.311 \\
\hline Working capital/Assets & 0.299 & 0.257 & 0.117 & 0.293 & 0.480 \\
\hline Very small firms & 0.098 & & & & \\
\hline Small firms & 0.432 & & & & \\
\hline Medium firms & 0.470 & & & & \\
\hline Young SMEs & 0.023 & & & & \\
\hline Dummy Construction & 0.147 & & & & \\
\hline Dummy Trade & 0.423 & & & & \\
\hline Dummy Hotel and Restaurant & 0.018 & & & & \\
\hline Dummy Info. and Communication & 0.020 & & & & \\
\hline Dummy Services & 0.145 & & & & \\
\hline Dummy Manufacturing industry & 0.247 & & & & \\
\hline
\end{tabular}

Notes: Number of observations: 52020 (17 104 enterprises in 2010, 17752 enterprises in 2011 e 17164 enterprises in 2012). Q1 and Q3 refer to the first and third quartiles, and Q2 refers to the median.

credit to firms is particularly important. Firms that are able to provide better guarantees to banks when negotiating a bank loan are able to borrow significantly more from banks.

In turn, the results of the credit demand function estimation suggest that, as we would expect, credit demand strongly depends on the interest rate. The negative effect of the amount of internal resources as measured by the firm's operational result, and the amount of external resources (loans granted by shareholders and accounts payable) 
Table 2 - Estimation results

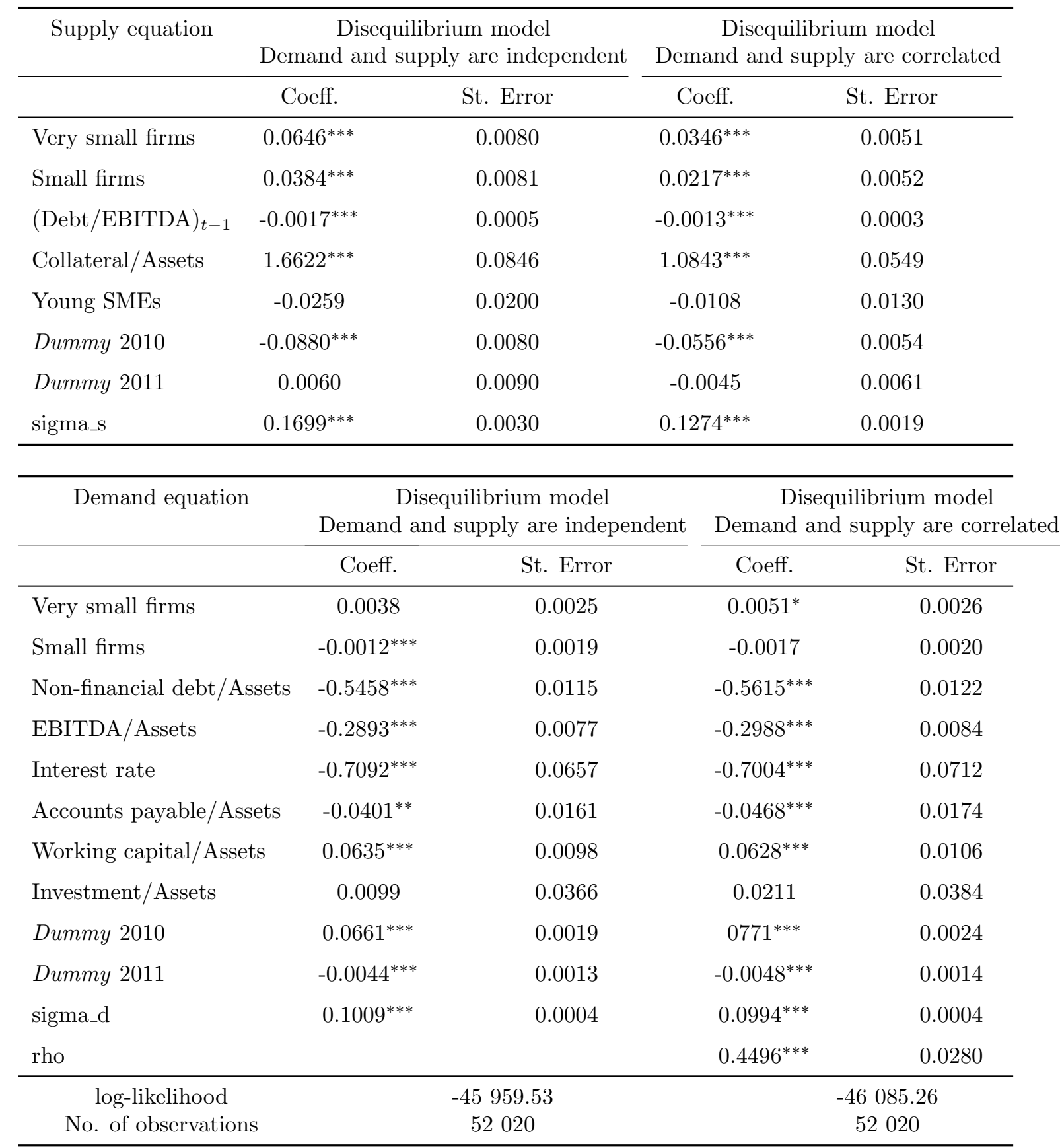

is in line with the hypothesis that due to information asymmetries, firms prefer other financing sources than bank loans (pecking order hypothesis).

The coefficient associated with investment is not statistically significant in both 
specifications. On the other hand, working capital needs affect credit demand. These two results may be related to some delay between granting credit and investment but also suggest that firms have demanded credit mainly to finance their operational activities rather than for investment projects. This result indicates that in the period of the financial and economic crisis in Portugal, the slowdown in firms' investment does not seem to be associated with credit restrictions, but with lower credit demand by firms, justified by the uncertainty about the future macroeconomic scenario.

Finally, in the model where credit demand and credit supply may be correlated the estimates suggest that smaller firms are those that most seek bank loans. This result is commonly found in the literature: smaller firms are not able to access alternative financing sources and tend to rely more on bank loans (see, for example, Gertler and Gilchrist (1994)).

\subsection{Credit rationing}

Table 3 presents the estimates associated to the probability that the latent credit demand is higher than the credit supply, leading to the presence of credit restrictions. The results for the intensive margin are reported in the first column and represent the percentage of firms that (with probability greater than 0.5 ) obtained a loan but in a lower amount than they applied for, given the interest rate. The results of full rationing are reported in the second column - extensive margin.

According to the results reported in the first column, approximately 15 percent of SMEs with a bank loan were partially rationed. The most affected firms by credit rationing are the younger, with approximately 26 percent, and the smaller firms with approximately 19 percent. The most affected activity sectors are construction and trade (21 percent and 16 percent, respectively).

The estimates for the extensive margin are reported in the second column of Table 3. The figures suggest that about 32 percent of Portuguese SMEs were affected by credit restrictions and did not get a loan even though their credit latent demand was positive. Smaller and younger firms are the most affected, but the estimates for the remaining dimension categories indicate that those were also considerably affected, with approximately 20 percent of larger SMEs facing credit restrictions. All the activity sectors faced credit restrictions, with estimates between 31 and 41 percent. 
Table 3 - Estimates (probability of credit rationing)

\begin{tabular}{lcc}
\hline & $\begin{array}{c}\text { Partial } \\
\text { (in \% of firms with loans) }\end{array}$ & $\begin{array}{c}\text { Full } \\
\text { (in of firms with no loan) }\end{array}$ \\
\hline SMEs & $15 \%$ & $32 \%$ \\
Very small firms & $19 \%$ & $35 \%$ \\
Small firms & $13 \%$ & $27 \%$ \\
Medium firms & $9 \%$ & $23 \%$ \\
Young SMEs & $26 \%$ & $29 \%$ \\
Manufacturing & $12 \%$ & $32 \%$ \\
Construction & $21 \%$ & $31 \%$ \\
Trade & $16 \%$ & $32 \%$ \\
Hotel and restaurant & $9 \%$ & $41 \%$ \\
Information and Communication & $11 \%$ & $32 \%$ \\
Other services & $14 \%$ & $32 \%$ \\
2010 & $41 \%$ & $59 \%$ \\
2011 & $3 \%$ & $19 \%$ \\
2012 & $3 \%$ & $22 \%$ \\
\hline
\end{tabular}

\section{Conclusions}

This study aims to identify the relative contribution of credit demand and supply factors in explaining the evolution of new loans granted to Portuguese small and medium-sized enterprises (SMEs). We voluntarily restrict the analysis to SMEs because we consider that larger firms have easier access to financing sources other than loans granted by resident banks and are, therefore, less exposed to credit restrictions. The methodology consists in the estimation of credit demand and credit supply functions simultaneously, assuming that the credit market may be in disequilibrium and, therefore, the interest rate does not lead to equilibrium in the demand and supply of credit. This methodology is particularly suitable since credit markets may be especially affected by information asymmetries between debtors and creditors. The results suggest that during the financial crisis Portuguese SMEs searched for bank loans mainly to finance their operational activity and not for investment. The smaller SMEs, with smaller amounts of internal resources have higher demand for bank loans. 
On the other hand, firms with a higher capacity to pay their debt and with more collateral can borrow more from banks.

The estimates relative to the intensive and extensive margins suggest that a significant fraction of Portuguese SMEs was affected by credit rationing. Furthermore, the results suggest that smaller and younger firms were the most credit constrained. 


\section{References}

Adelino, M., AND M. FerReira (2014): "Does sovereign credit risk affect bank lending? Evidence from sovereign rating downgrades," mimeo.

Antunes, A., And R. Martinho (2012): "Access to credit by non-financial firms," Financial Stability Report, May 2012, Banco de Portugal.

Atanasova, C. V., And N. Wilson (2004): "Disequilibrium in the UK corporate loan market," Journal of Banking and Finance.

Carbo-Valverde, S., F. Rodríguez-Fernandez, and G. F. Udell (2009): "Bank market power and SME financing constraints," Review of Finance, 13(2), 309-340.

FARINHA, L., AND S. FÉLIX (2014): "Análise do acesso ao crédito por empresas não financeiras," mimeo.

Fougère, D., C. Golfier, G. Horny, And E. Kremp (2012): "Did the crisis affect the survival of French firms?," mimeo, Banque de France.

Gersovitz, M. (1980): "Classification probabilities for the disequilibrium model," Journal of Econometrics, 14(2).

Gertler, M., AND Gilchrist (1994): "Monetary policy, business cycles, and the behavior of small manufacturing firms," The Quarterly Journal of Economics, 109(2).

Kremp, E., And P. Sevestre (2013): "Did the crisis induce credit rationing for French SMEs?," Journal of Banking and Finance, 37, 3757-3772.

LAFFont, J.-J., AND R. GARCIA (1977): "Disequilibrium econometrics for business loans," Econometrica, 45(5).

Maddala, G. S., AND F. D. Nelson (1974): "Maximum likelihood methods for models of markets in disequilibrium," Econometrica, 42(6).

Ogawa, K., And K. Suzuki (2000): "Demand for bank loans and investment under borrowing constraints: a panel study of Japanese bank data," Journal of the Japanese and International Economies, 14(1).

Rivers, D., And Q. H. Vuong (1988): "Limited information estimators and exogeneity tests for simultaneous probit models," Journal of Econometrics, 39, 347-366.

Rottmann, H., And T. WollmershäUser (2013): "A micro data approach to the identification of credit crunches," Applied Economics, 45(17).

Shikimi, M. (2005): "Do firms benefit from multiple banking relationships? Evidence from small and medium-sized firms in Japan," Working paper n 70, Hitotsubashi University 
Research Unit for Statistical Analysis in Social Sciences. 


\section{Appendix}

Table A1 Estimation results

\begin{tabular}{|c|c|c|c|c|}
\hline \multirow[t]{2}{*}{ Other estimates } & \multicolumn{2}{|c|}{$\begin{array}{c}\text { Disequilibrium model } \\
\text { Demand and supply are independent }\end{array}$} & \multicolumn{2}{|c|}{$\begin{array}{c}\text { Disequilibrium model } \\
\text { Demand and supply are correlatec }\end{array}$} \\
\hline & Coeff. & St. Error & Coeff. & St. Error \\
\hline \multicolumn{5}{|l|}{ Supply equation } \\
\hline Average $(\text { Debt/EBITDA })_{t-1}$ & $0.0030^{* * *}$ & 0.0006 & $0.0024^{* * *}$ & 0.0004 \\
\hline Average Young SMEs & 0.0369 & 0.0295 & $0.0362^{*}$ & 0.0197 \\
\hline Average Collateral/Assets & $-0.2407^{* * *}$ & 0.0764 & $-0.3095^{* * *}$ & 0.0419 \\
\hline Instrument: Collateral. residuals & $-0.4670^{* * *}$ & 0.0358 & $-0.2681^{* * *}$ & 0.0227 \\
\hline Initial value of $y$ & $-0.0749^{* * *}$ & 0.0134 & $-0.0359^{* * *}$ & 0.0089 \\
\hline \multicolumn{5}{|l|}{ Demand equation } \\
\hline Average Non-financial debt/Assets & $0.4557^{* * *}$ & 0.0131 & $0.4706^{* * *}$ & 0.0140 \\
\hline Average EBITDA/Assets & $0.1587^{* * *}$ & 0.0091 & $0.1565^{* * *}$ & 0.0100 \\
\hline Average Interest rate & $0.5580^{* * *}$ & 0.0219 & $0.6273^{* * *}$ & 0.0256 \\
\hline Average Accounts payable/Assets & $0.2721^{* * *}$ & 0.0118 & $0.2872^{* * *}$ & 0.0128 \\
\hline Average Investment/Assets & -0.0097 & 0.0122 & 0.0045 & 0.0128 \\
\hline Average Working capital/Assets & $-0.0514^{* * *}$ & 0.0080 & $-0.0549^{* * *}$ & 0.0087 \\
\hline Instrument: Interest rate. residuals & 0.0088 & 0.0649 & -0.0523 & 0.0701 \\
\hline Instrument: Accounts payable. residuals & $-0.2668^{* * *}$ & 0.0127 & $-0.2748^{* * *}$ & 0.0139 \\
\hline Instrument: Investment. residuals & 0.0463 & 0.0364 & 0.0258 & 0.0382 \\
\hline Instrument: Working capital. residuals & -0.0060 & 0.0070 & 0.0001 & 0.0076 \\
\hline Initial value of $y$ & $0.0312^{* * *}$ & 0.0034 & $0.0306^{* * *}$ & 0.0037 \\
\hline
\end{tabular}


Table A2 Estimation results

\begin{tabular}{|c|c|c|c|c|}
\hline \multirow[t]{2}{*}{ Other estimates } & \multicolumn{2}{|c|}{$\begin{array}{l}\text { Disequilibrium model } \\
\text { Demand and supply are independent }\end{array}$} & \multicolumn{2}{|c|}{$\begin{array}{l}\text { Disequilibrium model } \\
\text { Demand and supply are corr }\end{array}$} \\
\hline & Coeff. & St. Error & Coeff. & St. Error \\
\hline \multicolumn{5}{|l|}{ Supply equation } \\
\hline Dummy Construction & $0.0894^{* * *}$ & 0.0088 & $0.0586^{* * *}$ & 0.0056 \\
\hline Dummy Trade & $0.0667^{* * *}$ & 0.0074 & $0.0446^{* * *}$ & 0.0046 \\
\hline Dummy Hotel and restaurant & $-0.0545^{*}$ & 0.0307 & $-0.0482^{* * *}$ & 0.0173 \\
\hline Dummy Information and communication & $0.1793^{* * *}$ & 0.0403 & $0.0916^{* * *}$ & 0.0164 \\
\hline Dummy Services & $0.0336^{* * *}$ & 0.0095 & $0.0293^{* * *}$ & 0.0061 \\
\hline \multicolumn{5}{|l|}{ Demand equation } \\
\hline Dummy Construction & $0.0131^{* * *}$ & 0.0030 & $0.0134^{* * *}$ & 0.0031 \\
\hline Dummy Trade & -0.0034 & 0.0023 & $-0.0053^{* *}$ & 0.0025 \\
\hline Dummy Hotel and restaurant & $-0.0401^{* * *}$ & 0.0067 & $0.0408^{* * *}$ & 0.0069 \\
\hline Dummy Information and communication & $0.0232^{* * *}$ & 0.0067 & $0.0250^{* * *}$ & 0.0068 \\
\hline Dummy Services & $0.0490^{* * *}$ & 0.0030 & $0.0482^{* * *}$ & 0.0032 \\
\hline \multicolumn{5}{|l|}{ Supply and demand equations } \\
\hline Lagged loans, small, manufacturing & $0.7775^{* * *}$ & 0.0079 & $0.7665^{* * *}$ & 0.0079 \\
\hline Lagged loans, large, manufacturing & $0.8410^{* * *}$ & 0.0059 & $0.8347^{* * *}$ & 0.0059 \\
\hline Lagged loans, small, construction & $0.7281^{* * *}$ & 0.0088 & $0.7157^{* * *}$ & 0.0087 \\
\hline Lagged loans, large, construction & $0.7813^{* * *}$ & 0.0086 & $0.7720^{* * *}$ & 0.0085 \\
\hline Lagged loans, small, trade & $0.7779^{* * *}$ & 0.0051 & $0.7687^{* * *}$ & 0.0051 \\
\hline Lagged loans, large, trade & $0.8229^{* * *}$ & 0.0058 & $0.8190^{* * *}$ & 0.0058 \\
\hline Lagged loans, small, hotel & $0.7276^{* * *}$ & 0.0224 & $0.7126^{* * *}$ & 0.0220 \\
\hline Lagged loans, large, hotel & $0.7514^{* * *}$ & 0.0179 & $0.7449^{* * *}$ & 0.0177 \\
\hline Lagged loans, small, information & $0.7538^{* * *}$ & 0.0197 & $0.7394^{* * *}$ & 0.0196 \\
\hline Lagged loans, large, information & $0.8027^{* * *}$ & 0.0222 & $0.7994^{* * *}$ & 0.0222 \\
\hline Lagged loans, small, services & $0.7237^{* * *}$ & 0.0069 & $0.7150^{* * *}$ & 0.0069 \\
\hline Lagged loans, large, services & $0.7776^{* * *}$ & 0.0082 & $0.7749^{* * *}$ & 0.0082 \\
\hline
\end{tabular}




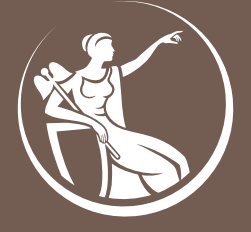

